\title{
Association of RETN +299(G>A) polymorphism with type two diabetes mellitus
}

\author{
Ghaith Altawallbeh¹, Omar F. Khabour²⿴, Mahmoud A. Alfaqih³, Muayad M. Abboud, \\ Mohammad Y. Gharibeh'1 and Najeeb A. Mohammed² \\ 'Department of Laboratory Medicine and Pathology, University of Minnesota, Minnesota, USA; 2Department of Medical Laboratory Sciences, \\ Jordan University of Science and Technology, Irbid, Jordan; ${ }^{3}$ Department of Physiology and Biochemistry, Jordan University of Science and \\ Technology, Irbid, Jordan; ${ }^{2}$ Department of Basic Medical Sciences, Hashemite University, Jordan
}

The global prevalence of type-two diabetes mellitus (T2DM) makes it a disease of public health concern. T2DM is strongly linked with insulin resistance caused by increased levels of visceral fat. Visceral fat secretes several adipocytokines that regulate body metabolism. Resistin is one of these adipocytokines which is encoded by the RETN gene. Herein, we tested the association of the RETN +299(G>A) and $-420(\mathrm{C}>\mathrm{G})$ single nucleotide polymorphisms (SNPs) with T2DM. T2DM patients $(n=282)$ and healthy subjects $(n=125)$ were included in the study. Subjects with metabolic syndromes other than diabetes were excluded. Genotyping of subjects was performed using PCR-RFLP. The +299 (G $>$ A) SNP was associated with T2DM $(P=0.038)$. The AA genotype was higher in T2DM (17\%) compared to controls (8\%) with an odd ratio of 2.16 and $95 \% \mathrm{Cl}$ of 1.34 to 4.56 . With respect to $-420(C>G)$ SNP, no significant association was found with the risk of T2DM ( $P=0.128)$. The haplotype analysis of the examined SNPs indicated that the CA haplotype of the -420 and +299 SNPs in RETN was associated with T2DM risk ( $P=0.004$; odd ration $4.0,95 \% \mathrm{Cl}$ : $1.56-10.0)$. In conclusion, the present findings suggest a role of the RETN locus in modulating the risk of T2DM.

Keywords: resistin, type two diabetes mellitus, single nucleotide polymorphisms, haplotype, risk, +299 SNP, -420 SNP

Received: 30 June, 2020; revised: 10 October, 2020; accepted: 04 November, 2020; available on-line: 07 March, 2021

『e-mail: khabour@just.edu.jo

Acknowledgements of Finanacial Support: The study was fully funded by Jordan University of Science and Technology.

Abbreviations: ADA, American diabetes association; BF, Body fat BMI, Body mass index; BW, body weight; DM, diabetes mellitus; FBG, Fasting blood glucose; HOMA, Homeostatic model assessment; LBM, Lean body mass; PCR-RFLP, Polymerase chain reactionrestriction fragment length polymorphism; SNP, Single nucleotide polymorphism; T2DM, Type-two diabetes mellitus

\section{INTRODUCTION}

Diabetes mellitus (DM) is a debilitating metabolic disease linked with atherosclerosis, hypertension and kidney failure (Schmidt, 2018). In 2015, more than 400 million people were diagnosed with DM, with the majority of the patients living in low to middle income countries. The disease is currently recognized as a heterogeneous group of diseases manifested by chronic hyperglycemia. The most common form of DM is type two (T2DM), which is caused by insulin resistance in target cells in the body (Schmidt, 2018). T2DM is strongly linked with abdominal obesity; a major cause of insulin resistance
(Kahn et al., 2006). Interestingly, some individuals appear to be genetically more predisposed than others to developing T2DM. Indeed, genetic variations in several loci has been found to modulate the risk of T2DM in the human population (Ingelsson \& McCarthy, 2018).

Abdominal obesity is associated with visceral fat accumulation and insulin resistance. Visceral fat has been shown to secrete several hormones, known as adipocytokines, which appear to modify the tissues' response to insulin secretion (Ouchi, 2016). Resistin, a cysteine rich protein, is an example of one of these hormones. In a case-control study performed on T2DM patients attending a tertiary hospital in Jordan, Gharibeh and colleagues reported that resistin levels were higher in T2DM compared to non-diabetic subjects (Gharibeh et al., 2010). Interestingly, in the case of T2DM, positive correlations were reported between the serum resistin concentration and the HOMA (Homeostatic Model Assessment) index, which reflects insulin resistance in patients (Gharibeh et al., 2010).

Resistin is encoded by the RETN gene (Hu et al., 2015). Genetic variants in the RETN gene may affect resistin expression and consequently its levels (Hivert et al., 2009). Given the association between the resistin protein and T2DM, we hypothesized that RETN gene variants may modulate the risk of T2DM.

The two commonly investigated SNPs in RETN gene are $-420(\mathrm{C}>\mathrm{G})$ and $+299(\mathrm{G}>\mathrm{A})$ (Amal et al., 2013; Wen et al., 2013). The $-420(C>G)$ is found in the promoter region and was shown to affect RETN transcription and the subsequent resistin level (Azuma et al., 2004, Osawa et al., 2004). The +299 (G>A) SNP is located in the 2nd intron and was also shown to be associated with resistin level. Previous literature has shown that +299 SNP was associated with T2DM in different populations (Chung et al., 2014, de Luis et al., 2020, Thammakun et al., 2017, Zhang et al., 2013). Similarly, -420 SNP has been shown to be associated with T2DM among Pakistani population (Nadeem et al., 2018). Herein, we tested the association of the $-420(\mathrm{C}>\mathrm{G})$ and $+299(\mathrm{G}>\mathrm{A})$ SNPs in RETN gene with T2DM among Jordanians.

\section{MATERIALS AND METHODS}

\section{Design and participants}

The study design included a retrospective case-control. Institutional Review Boards of the Jordan University of Science and Technology (JUST) and King Abdullah 
Table 1. Primers and enzymes used for RFLP analysis of single nucleotide polymorphisms of the RETN gene.

\begin{tabular}{lllc}
\hline SNP & Primer & Sequence 5 ' to '3 & Amplicon size (bps) \\
\hline$+299(G>A)$ & $\begin{array}{l}\text { Forward } \\
\text { Reverse }\end{array}$ & $\begin{array}{l}\text { GAGAGGATCCAGGAGGTC } \\
\text { GTGAGACCAAACGGTCCCTG }\end{array}$ & 533 \\
& $\begin{array}{l}\text { Forward } \\
\text { Reverse }\end{array}$ & $\begin{array}{l}\text { TGTCATTCTCACCCAGAGACA } \\
\text { TGGGCTCAGCTAACCAAATC }\end{array}$ & B enzyme \\
\hline
\end{tabular}

University Hospital (KAUH) approved the study. Study participants were required to sign a consent form prior to their enrollment. Subjects were recruited at the outpatient clinics of KAUH, a tertiary hospital affiliated with JUST.

A total of four hundred and seven subjects were enrolled in this study. Two hundred and eighty-two participants were T2DM patients diagnosed by endocrinologists according to the American Diabetes Association (ADA) criteria that include fasting blood sugar greater than or equal to $126 \mathrm{mg} / \mathrm{dl}$ and $\mathrm{HbA1c} \geq 6.5$. Subjects with diabetes were patients actively treated for T2DM at the Endocrinology Clinics of KAUH. A total of 125 control non-diabetes subjects were recruited during their visit to other KAUH clinics. Based on a short interview, it was determined that the control subjects did not complain of any of the usual symptoms associated with T2DM at the time of their recruitment. Moreover, control subjects were requested to measure their 12hour fasting blood glucose (FBG) and HbA1c levels at two separate times to confirm the absence of T2DM. Control group participants with repeated FBG of 100 to $125 \mathrm{mg} / \mathrm{dL}$ or a HgbA1c between (5.7-6.4)\% were excluded. Subjects with metabolic syndromes other than diabetes, Cushing's syndrome, and thyroid diseases were also excluded from the study. All recruited participants were of Jordanian descent and patients from other nationalities were excluded.

\section{Anthropometric measurements}

During the subject's visit to KAUH clinics the height $(\mathrm{H}$, in $\mathrm{cm})$ and body weight $(\mathrm{BW}$, in $\mathrm{Kg}$ ) of the subjects were recorded. The height and BW were then used to compute the body mass index (BMI) according to the mathematical formula: $\mathrm{BMI}=\mathrm{BW}(\mathrm{kg}) /$ $\mathrm{H}^{2}\left(\mathrm{~m}^{2}\right)$. Lean body mass (LBM) was calculated in men using the formula: LBM $(\mathrm{kg})=0.32810 \times \mathrm{BW}(\mathrm{kg})$ $+0.33929 \times \mathrm{H}(\mathrm{cm})-29.5336$, and in women using the formula: $\operatorname{LBM}(\mathrm{kg})=0.29569 \times \mathrm{BW}(\mathrm{kg})+0.41893 \times \mathrm{H}$ $(\mathrm{cm})-43.2933$. Body fat $(\mathrm{BF})$ was calculated from the body weight (BW) and LBM using the following equation: $\mathrm{BF}=\mathrm{BW}-\mathrm{LBM}$.

\section{Blood sampling}

The blood was collected from the subjects following a 12-hour fast. $4 \mathrm{~mL}$ was collected into an evacuated EDTA tube, and $5 \mathrm{~mL}$ into a plain tube (AFCO, Amman, Jordan). EDTA blood was used to measure HbA1c levels and the remainder was used for DNA extraction as described below. Plain blood was centrifuged at $4500 \times \mathrm{g}$ for $5 \mathrm{~min}$ to obtain the serum for the measurement of FBG, triglycerides, and lipid profile (total cholesterol, HDL, and LDL).

\section{Biochemical measurements}

Serum samples collected from the subjects were submitted to the laboratories of KAUH to measure glucose and lipid profile using an automated biochemical analyz- er obtained from Roche Diagnostics (Germany). HbA1c was measured in EDTA collected blood using the above system as well.

\section{Molecular analysis}

DNA was extracted from whole blood using QIAamp DNA extraction Kit purchased from Qiagen (Germany). The concentration and the purity of the extracted DNA was assessed at 260 OD and 260/280 OD ratio respectively using a Nanodrop machine obtained from Thermo Fisher (MA, USA). Analysis of the $-420(\mathrm{C}>\mathrm{G})$ or $+299(\mathrm{G}>\mathrm{A})$ polymorphisms in the RETN gene was achieved using polymerase chain reaction followed by restriction fragment length polymorphism analysis. All PCR reactions were performed in $20 \mu \mathrm{L}$ final volume using ready to use master mix obtained from Promega Company (WI, USA), $10 \mathrm{ng}$ of DNA and .2 $\mu \mathrm{M}$ of each of each primer. The sequences of the used primers, PCR amplicon size, PCR cycling parameters and the restriction enzyme conditions are listed in Table 1 . All restriction enzymes were purchased from NEB (New England Biolabs, MA). The undigested PCR products and the fragments that resulted from the restriction enzyme digestion were separated using 2.5\% agarose gel electrophoresis stained with ethidium bromide. The sizes of restricted DNA fragments were estimated under UV light and a proper DNA ladder.

\section{Statistical analysis}

Demographic characteristics and biochemical parameters (HbA1c, blood glucose, triglycerides, and lipid profile), $\mathrm{BMI}$, and $\mathrm{BF}$ were compared between the control group and T2DM patients using the Student's $t$-test. The frequencies of the different genotype categories and alleles of each SNP were compared between the control group and T2DM patients using the SNPStats software tool that is widely used in genetic association studies (http:// bioinfo.iconcologia.net/SNPstats). Haplotype analysis of RETN polymorphisms was performed using the above tool as well. The power analysis was carried out using G. Power version 3.0.10 (Franz Faul, Universität Kiel, Kiel, Germany). In all tests, the power was more than 60 .

\section{RESULTS}

Table 2 presents the characteristics of patients and controls. T2DM patients were similar in mean age to the controls (52.90 vs. 52.02; $P>0.05$ ). Male participants represented $51.2 \%$ of the control group and $47.5 \%$ of the patient group. Significant differences in FBG $(P<0.001)$, HbA1c $(P<0.001)$, triglyceride $(P<0.05)$, and BMI $(P<0.05)$ were found between the control and patient groups. No significant differences between the compared groups were found in total cholesterol, LDL, HDL, and percent BF..

We next tested the association of RETN $-420(\mathrm{C}>\mathrm{G})$ or $+299(\mathrm{G}>\mathrm{A})$ SNPs with T2DM. Geno- 
Table 2. Baseline characteristics of the control and patient groups

\begin{tabular}{llll}
\hline Parameter * & Control group & Patient group & $P$ value \\
\hline Mean age: year & $51.95(11.40)$ & $53.94(9.26)$ & 0.063 \\
\hline Gender N (\%) & & & 0.470 \\
\hline Male & $64(51.2)$ & $134(47.5)$ & $148(52.5)$ \\
\hline Female & $61(48.8)$ & $9.65(5.47)$ & $<.001$ \\
\hline Fasting blood sugar & $5.50(.57)$ & $7.36(1.76)$ & $<0.001$ \\
\hline HbA1c $(\%):$ & $5.79(.51)$ & $5.00(1.42)$ & 0.536 \\
\hline Total cholesterol $(\mathrm{mmol} / \mathrm{L})$ & $4.87(1.02)$ & $2.39(2.03)$ & 0.013 \\
\hline Triglyceride $(\mathrm{mmol} / \mathrm{L})$ & $1.90(1.27)$ & $1.01(.34)$ & 0.249 \\
\hline HDL $(\mathrm{mmol} / \mathrm{L})$ & $0.97(.28)$ & $3.22(1.15)$ & 0.471 \\
\hline LDL $(\mathrm{mmol} / \mathrm{L})$ & $3.26(.90)$ & $31.14(5.30)$ & 0.015 \\
\hline BMI $\left(\mathrm{Kg} / \mathrm{m}^{2}\right)$ & $29.8(4.81)$ & $32.29(10.8)$ & 0.164 \\
\hline Body fat & $30.6(9.0)$ & & \\
\hline
\end{tabular}

*All parameters were expressed as mean (SD) except gender as $\mathrm{N}(\%)$

Table 3. Association between RETN SNPs and the risk of diabetes mellitus

\begin{tabular}{|c|c|c|c|c|}
\hline RETN SNP & Cases N (\%) & Controls N (\%) & Odd Ratio $(95 \% \mathrm{Cl})$ & $P$ value \\
\hline \multicolumn{5}{|l|}{+299} \\
\hline GG & $142(50)$ & $64(51)$ & 1.00 & \multirow{3}{*}{0.038} \\
\hline GA & $92(33)$ & $51(41)$ & $1.23(0.78-1.93)$ & \\
\hline AA & $48(17)$ & $10(8)$ & $2.16(1.34-4.56)$ & \\
\hline Allele G & $376(67)$ & $179(72)$ & & \multirow{2}{*}{0.163} \\
\hline Allele A & $188(33)$ & $71(28)$ & & \\
\hline-420 & N (\%) & N (\%) & & \\
\hline CC & $95(34)$ & $35(28)$ & 1.00 & \multirow{3}{*}{0.128} \\
\hline GC & $161(57)$ & $73(58)$ & $0.81(0.50-1.31)$ & \\
\hline GG & $26(9)$ & $17(14)$ & $0.56(0.27-1.16)$ & \\
\hline Allele C & $351(62)$ & $143(57)$ & & \multirow{2}{*}{0.174} \\
\hline Allele G & 213 (38) & $107(43)$ & & \\
\hline
\end{tabular}

type and allele frequencies of each SNP in the control or patient groups are presented in Table 3. Our findings indicated a significant association between $+299(\mathrm{G}>\mathrm{A})$ genotypes and T2DM $(P<0.05)$. Specifically, the AA genotype was more common in the T2DM group $(17 \%)$ compared to the control group $(8 \%)$. Accordingly, AA was associated with an increased risk of T2DM than other genotypes. The frequency of the A allele was higher in the patient group compared to the controls but without statistical significance $(P=0.163)$. With respect to $-420(C>G)$ SNP, no significant association was found between the genotypes or alleles of this SNP and the risk of T2DM (Table 3). With respect to Hardy-Weinberg test, the $299(\mathrm{G}>\mathrm{A}) \mathrm{SNP}$ was in equilibrium $(P=0.971)$, whereas the RETN $-420(\mathrm{C}>\mathrm{G})$ SNP was not in equilibrium $(P=0.031)$.

Table 4 presents the results of haplotype analysis of RETN gene polymorphisms examined in this investigation. Our findings demonstrated that the CA haplotype was significantly $(P<0.01)$ enriched in the patients $(12.5 \%)$ compared to the controls $(2.5 \%)$. It can thus be concluded that the CA haplotype of RETN -420 and +299 SNPs increased the risk of T2DM in this population. No significant association between the three other haplotypes (i.e.. GG, GA, or CG) and T2DM was detected in our population $(P>0.05)$. Linkage disequilibrium analysis of the examined SNPs was $D=0.1055$, $D^{\prime}=0.5618$, and $r=0.4674$.

Table 4. Analysis of the association of RETN haplotypes with the risk of T2DM

\begin{tabular}{lllll}
\hline & Cases Frequency & Controls Frequency & OR $(95 \% \mathrm{Cl})$ & $P$-value \\
\hline CG & 50.2 & 54.7 & 1.00 & 0.350 \\
\hline GA & 21.4 & 25.9 & $0.83(0.56-1.22)$ & 0.820 \\
\hline GG & 16.4 & 16.9 & $0.94(0.59-1.5)$ & 0.004 \\
\hline CA & 12.0 & 2.5 & $4.0(1.56-10.0)$ & 0.0 \\
\hline
\end{tabular}


Finally, we performed cross tabulation analysis between the genotypes of examined SNPs and the biochemical parameters presented in Table 2. None of these parameters were found to be associated with SNPs genotypes $(P>0.05$, data not shown).

\section{DISCUSSION}

T2DM is strongly linked with insulin resistance and abdominal obesity. The exact mechanism that explains the relationship between abdominal obesity and T2DM is currently unknown, but could be related to changes in the secretory profile of visceral fat, which is a type of fat that surrounds internal organs and most often increases in abdominal obesity.

Several hormones secreted from visceral fat tissue, known as adipocytokines, appear to modify the response of tissues to insulin activity (Alfaqih et al., 2018). Resistin is an adipocytokine secreted by visceral fat cells (Fain et al., 2003). A previous report demonstrated an association between resistin protein and an increased risk of T2DM (Gharibeh et al., 2010). Genetic variants of the gene that codes for resistin, called RETN, were shown to be linked with altered levels of resistin protein in a number of populations (Chen et al., 2010; Zayani et al., 2018). Given these reports, we tested the association of two single nucleotide polymorphisms in RETN, $-420(\mathrm{C}>\mathrm{G})$ and $+299(\mathrm{G}>\mathrm{A})$, with T2DM.

We demonstrated in this study that the $+299(\mathrm{G}>\mathrm{A})$ SNP was associated with T2DM. Specifically, we found that the AA genotype of the $+299(\mathrm{G}>\mathrm{A}) \mathrm{SNP}$ was more frequently observed in T2DM patients than in controls. Given this result, it may be presumed that the relatively infrequent AA genotype of this SNP may be associated with an increased risk of T2DM as well. Although our findings indicated a higher frequency of the A allele in the patients compared to the controls, our results did not reach statistical significance. A larger sample size with greater statistical power may be needed to demonstrate that the A allele of the $+299(\mathrm{G}>\mathrm{A})$ SNP in RETN is associated with an increased risk of T2DM. The role of RETN SNPs in modulating the risk of T2DM was demonstrated in previous studies conducted in other populations (Chung et al., 2014; de Luis et al., 2020; Thammakun et al., 2017; Zhang et al., 2013). In agreement with the present finding, +299(G>A) SNP was found to be associated with T2DM among Chinese population (Chung et al., 2014; Zhang et al., 2013). In a recent meta-analysis, a significant association was observed between $+299(\mathrm{G}>\mathrm{A})$ SNP and T2DM, with a pooled odds ratio of 1.45 (95\% CI 1.10-1.92) (Kumar et al., 2020). In addition, The SNPs 3'UTR $\mathrm{C} / \mathrm{T}$ and $+62 \mathrm{G}>\mathrm{A}$ of RETN gene were found to be associated with T2DM in Spaniards and Thais, respectively (de Luis et al., 2020, Thammakun et al., 2017). Moreover, a study that was conducted in Pakistan showed an association between the $G$ allele of RETN -420 SNP and the risk of T2DM (Nadeem et al., 2018). The RETN SNPs were also found to be associated with obesity and metabolic syndrome parameters that are related to diabetes (Boumaiza et al., 2012; Hivert et al., 2009; Menzaghi et al., 2006). These findings collectively suggest a role for RETN SNPs in the risk of T2DM in the different populations.

The $+299(\mathrm{G}>\mathrm{A})$ SNP is located in the second intron of the RETN gene (Suriyaprom et al., 2009). Several explanations may explain the association of this SNP with T2DM (El-Shal et al., 2013; Li et al., 2007; Rode et al., 2019; Suriyaprom et al., 2009). For example, this SNP may be in linkage disequilibrium with another SNP that modulates level of gene expression of resistin, similar to that reported between -358 and +420 RETN SNPs (Onuma et al., 2010). Another explanation would be that this SNP could be part of a sequence motif or a regulatory element that mediates the binding of a coregulatory protein involved in the regulation of RETN gene expression, similar to that reported for other RETN SNPs (Osawa et al., 2004). Finally, the SNP could be part of a micro-RNA transcript (Li et al., 2007), which regulates the stability of a gene transcript involved in the pathophysiology of T2DM. The confirmation of any of the above hypothesis requires further experiments performed on relevant cell and/or animal models and are beyond the scope of the current investigation.

Association studies based on haplotype analysis of several SNPs are believed to have more statistical power than those based on individual SNPs (Bashir et al., 2019; Bader, 2001). Herein, we carried haplotype analysis of both SNPs in the RETN gene that were also examined individually for their association with T2DM. We found that one of the haplotypes, CA, was significantly more frequent in the T2DM cases than in controls, which indicates that this haplotype increases the risk of T2DM. This result is in line with our observation that the AA genotype of the $+299(\mathrm{G}>\mathrm{A})$ SNP is significantly more frequent in $\mathrm{T} 2 \mathrm{DM}$ patients.

In this investigation, data related to the presence of cardiomyopathy and/or other diabetic complications were not collected by the research team. This is a limitation of this study as there are a number of reports that indicated dysregulation in resistin levels in diabetic patients suffering from cardiomyopathy (Lebeche, 2015). It could thus be assumed that genetic variants in the RETN locus could modulate the risk of cardiomyopathy or other complications in T2DM patients (Hussain et al., 2010). However, the above hypothesis was not tested in this investigation and could be a subject for future investigations. Another limitation was that the sample represented a single tertiary institution from one geographic area in Jordan. Further validation of the findings presented in this study is thus required using data extracted from patients from several geographic regions.

\section{CONCLUSIONS}

This study reported an association between the +299 AA genotype in the RETN gene and T2DM. This result provides further support to the role of the RETN locus in mediating the risk of T2DM. The findings of this report, however, require further testing in a larger population.

\section{Acknowledgements}

The authors thank Mr. Mohammad Alzubi who provided technical support for the study.

\section{REFERENCES}

Alfaqih MA, Khader YS, Al-Dwairi AN, Alzoubi A, Al-Shboul O, Hatim, A (2018) Lower levels of serum adiponectin and the $T$ allele of rs1501299 of the ADIPOQ gene are protective against polycystic ovarian syndrome in Jordan. Korean J Fam Med 39: 108. https:// doi. org/10.4082/kjfm.2018.39.2.108

El-Shal AS, Pasha HF, Rashad NM (2013) Association of resistin gene polymorphisms with insulin resistance in Egyptian obese patients. Gene 515: 233-238. https://doi.org/10.1016/j.gene.2012.09.136

Bader JS (2001) The relative power of SNPs and haplotype as genetic markers for association tests. Pharmacogenomics 2: 11-24. https://doi. org/10.1517/14622416.2.1.11 
Bashir NA, Morad FR, Khabour OF, AlFaqih MA, Khassawneh BY (2019) The EGFR rs2233947 polymorphism is associated with lung cancer risk: a study from Jordan. Acta Biochim Pol 66: 315-319. https://doi.org/10.18388/abp.2019_2781

Chen BH, Song Y, Ding EL, Manson JE, Roberts CK, Rifai N, Buring JE, Gaziano JM, Liu S (2010) Association of resistin promoter polymorphisms with plasma resistin levels and type 2 diabetes in women and men. Int J Mol Epidemiol Genet 1: 167-174. PMID: 21116434

de Luis Román DA, Gómez Hoyos E, Ortolá A, Delgado E, Díaz G, Torres B, López JJ (2020) The rs10401670 variant of the resistin gene is related to circulating resistin levels, insulin resistance, and presence of type-2 diabetes mellitus in obese patients. Nutr Hosp 37: 293-298. https://doi.org/10.20960/nh.02896 (in Spanish)

El-Shal AS, Pasha HF, Rashad NM (2013) Association of resistin gene polymorphisms with insulin resistance in Egyptian obese patients. Gene 515: 233-238. https://doi.org/10.1016/j.gene.2012.09.136

Fain JN, Cheema PS, Bahouth SW, Lloyd Hiler M (2003) Resistin release by human adipose tissue explants in primary culture. Biochem Biophys Res Commun 300: 674-678. https://doi.org/10.1016/s0006291x(02)02864-4

Gharibeh MY, Al Tawallbeh GM, Abboud MM, Radaideh A, Alhader AA, Khabour OF (2010) Correlation of plasma resistin with obesity and insulin resistance in type 2 diabetic patients. Diabetes Metab 36: 443-449. https://doi.org/10.1016/j.diabet.2010.05.003

Hivert MF, Manning AK, McAteer JB, Dupuis J, Fox CS, Cupples LA, Meigs JB, Florez JC (2009) Association of variants in RETN with plasma resistin levels and diabetes-related traits in the Framingham Offspring Study. Diabetes 58: 750-756. https://doi.org/10.2337/ db08-1339

Hu Q, Tan H, Irwin DM (2015) Evolution of the vertebrate Resistin Gene family. PloS One 10: e0130188. https://doi.org/10.1371/journal.pone. 0130188

Hussain S, Asghar M, Javed Q (2010) Resistin gene promoter region polymorphism and the risk of hypertrophic cardiomyopathy in patients. Transl Res 155: 142-147. https://doi.org/10.1016/j. trsl.2009.10.002

Ingelsson E, McCarthy MI (2018) Human genetics of obesity and type 2 diabetes mellitus: past, present, and future. Circ Genom Precis Med 11: e002090. https://doi.org/10.1161/CIRCGEN.118.002090

Kahn SE, Hull RL, Utzschneider KM (2006) Mechanisms linking obesity to insulin resistance and type 2 diabetes. Nature 444: 840-846. https://doi.org/10.1038/nature05482

Kumar V, Singh J, Aneja A, Singh J (2020) Association of RETN gene polymorphism at $+299 \mathrm{G}>\mathrm{A}$ with type 2 diabetes mellitus: a meta-analysis. Int J Diabetes Develop Countries 40: 12-20. https://doi. org/10.1007/s13410-019-00746-x

Lebeche D (2015) Diabetic cardiomyopathy: is resistin a culprit? Cardiovasc Diagn Ther 5: 387. https://doi.org/10.3978/j.issn.22233652.2015.05.04

Li SC, Tang P, Lin WC (2007) Intronic microRNA: discovery and biological implications. DNA Cell Biol 26: 195-207. https://doi. org/10.1089/dna.2006.0558

Menzaghi C, Coco A, Salvemini L, Thompson R, De Cosmo S, Doria A, Trischitta V (2006) Heritability of serum resistin and its genetic correlation with insulin resistance-related features in nondia- betic Caucasians. J Clin Endocrinol Metab 91: 2792-2795. https://doi. org/10.1210/jc.2005-2715

Nadeem A, Mumtaz S, Saif MW, Naveed AK, Aslam M, Mansoor Q, Siddiqui A, Ismail M (2018) Association of RETN C-420G single nucleotide polymorphism with type 2 diabetes mellitus in Pakistani Punjabi Rajput population. J Pak Med Assoc 68: 1584-1589. PMID: 30410133

Onuma H, Tabara Y, Kawamura R, Tanaka T, Ohashi J, Nishida W, Takata Y, Ochi M, Yamada K, Kawamoto R, Kohara K, Miki T, Makino H, Osawa H (2010) A at single nucleotide polymorphism-358 is required for $G$ at -420 to confer the highest plasma resistin in the general Japanese population. PLoS One 5: e9718. https://doi.org/10.1371/journal.pone.0009718

Osawa H, Yamada K, Onuma H, Murakami A, Ochi M, Kawata H, Nishimiya T, Niiya T, Shimizu I, Nishida W, Hashiramoto M, Kanatsuka A, Fujii Y, Ohashi J, Makino H (2004) The G/G genotype of a resistin single-nucleotide polymorphism at -420 increases type 2 diabetes mellitus susceptibility by inducing promoter activity through specific binding of Sp1/3. Am J Hum Genet 75: 678-686. https: / / doi.org/10.1086/424761

Ouchi N (2016) Adipocytokines in cardiovascular and metabolic diseases. J Atherosc Thromb 23: 645-654. https://doi.org/10.5551/ jat.34918

Rode PA, Kolte RA, Kolte AP, Purohit HJ, Ahuja CR (2019) Relevance of single-nucleotide polymorphism to the expression of resistin gene affecting serum and gingival crevicular fluid resistin levels in chronic periodontitis and type 2 diabetes mellitus: A randomized control clinical trial. J Indian Soc Periodontol 23: 131-136. https://doi. org/10.4103/jisp.jisp_361_18

Schmidt AM (2018) Highlighting diabetes mellitus: the epidemic continues. Arterioscler Thromb V asc Biol 38: e1-e8. https://doi.org/10.1161/ ATVBAHA.117.310221

Suriyaprom K, Phonrat B, Namjuntra P, Chanchay S, Tungtrongchitr $\mathrm{R}$ (2009) The+ 299 (G> A) resistin gene polymorphism and susceptibility to type 2 diabetes in Thais. J Clin Biochem Nutr 44: 104 110. https://doi.org/10.3164/jcbn.08-224

Thammakun T, Laohasiriwong W, Kraiklang R, Saengprajak N (2017) Association of $+62 \mathrm{G}>\mathrm{A}$ polymorphism in the resistin gene with type 2 diabetes mellitus among Thais: case-control study. J Clin Diagn Res 11: BC15-BC20. https://doi.org/10.7860/ JCDR/2017/25072.9390

Wen Y, Lu P, Dai L (2013) Association between resistin gene- 420 $\mathrm{C} / \mathrm{G}$ polymorphism and the risk of type 2 diabetes mellitus: a metaanalysis. Acta Diabetol 50: 267-272. https://doi.org/10.1007/s00592010-0247-8

Zayani N, Hamdouni H, Boumaiza I, Achour O, Neffati F, Omezzine A, Najjar MF, Bouslama A (2018) Resistin polymorphims, plasma resistin levels and obesity in Tunisian volunteers. J Clin Lab Anal 32: e22227. https://doi.org/10.1002/jcla.22227

Zhang LY, Jin YJ, Jin QS, Lin LY, Zhang DD, Kong LL (2013) Association between resistin $+299 \mathrm{~A} / \mathrm{A}$ genotype and nonalcoholic fatty liver disease in Chinese patients with type 2 diabetes mellitus. Gene 529: 340-344. https://doi.org/10.1016/j.gene.2013.08.001 